\title{
URGENSI PERUBAHAN \\ SIFAT TINDAK PIDANA PERZINAAN DI INDONESIA \\ DARI TINDAK PIDANA ADUAN \\ MENJADI TINDAK PIDANA BIASA
}

\author{
Maulidin Darma Wangsa \\ e-Mail: maulidin.darma@gmail.com
}

\begin{abstract}
Abstrak
KUHP merupakan produk hukum Belanda yang berdasarkan nilai-nilai individualisme dan liberalisme yang bertolak belakang dengan hukum dan budaya bangsa Indonesia. Hal ini terlihat dalam Pasal 284 KUHP tentang zina, perbuatan zina tidak dapat dilakukan penuntutan jika tidak adanya aduan.

Tujuan dari penelitian ini ialah untuk menganalisis perlunya perubahan sifattindak pidana perzinaan dalam KUHP Indonesia menjadi tindak pidana biasa, dan membuat formulasi tindak pidana perzinaan dalam KUHP Indonesia yang akan datang agar menjadi tindak pidana biasa. Dalam penelitian ini menghasilkan: Pertama, berdasarkan analisis terhadap putusan-putusan pengadilan, gambaran kondisi dan reaksi masyarakat, kasuskasus zina yang tidak diadukan dan alasan pembenar perlunya perubahan sifat tindak pidana zina, maka perlu dilakukan perubahan sifat tindak pidana zina menjadi tindak pidana biasa. Kedua, agar bersifat tindak pidana biasa perlu dilakukan perubahan dengan mereformulasi Pasal 284 KUHP dengan menggunakan Teori Perubahan dan Pembentukan Undang-Undang. Hal tersebut dapat dilakukan selama Pasal tersebut bertentangan dengan Pancasila.
\end{abstract}

Kata Kunci: Perzinaan, Delik Aduan, Delik Biasa, Reformulasi Kebijakan

\begin{abstract}
Criminal Code is the Dutch legal product based on the individualism and liberalism values which are contrary to the laws and cultures of Indonesian people. It is seen from the Article 284 of the Criminal Code on Adultery stating that fornication cannot be prosecuted if no accusation is made.

This research is aimed at analyzing the necessity of changing the characteristics of adultery criminal act in the Indonesia Criminal Code into ordinary criminal act and of making a formula of adultery criminal act in the Indonesia Criminal Act into an ordinary criminal act in the future. The results of this research are as follows. Firstly, on the basis of the analysis of the court decisions, the picture of the condition and reactions of the people, adultery cases which were not complained and the reasons supporting the necessity of changing the characteristics of the criminal act of adultery, it is necessary to make changes of the characteristics of the criminal act of adultery into an ordinary criminal law. Secondly, in order to have characteristics of an ordinary criminal act, it is necessary to make some changes by reformulating the Article 284 of the Criminal Code using the theory of changes and establishment of law. This can be made as long as the article is contradictory with Pancasila (Five Basic Principles).
\end{abstract}

Key words: Adultery, Criminal complaint, Ordinary complaint, Policy reformulation 


\section{PENDAHULUAN}

Pada awalnya KUHP dipandang sebagai induk dan sebagai wujud dari kodifikasi dan unifikasi. Namun dalam perkembangan selanjutnya, KUHP dipandang belum lengkap atau belum dapat menampung berbagai masalah dalam dimensi perkembangan bentuk-bentuk tindak pidana baru, serta kurang sesuai dengan nilai-nilai sosio filosofik, sosio politik, dan sosio kultural yang hidup dalam masyarakat.

Gagasan pembaruan pada hukum nasional, khususnya hukum pidana (KUHP) telah lama direncanakan. Usaha pembaruan tersebut berdasarkan pada fakta bahwa KUHP yang sedang berlaku sekarang ini merupakan produk hukum warisan kolonial Belanda, dan falsafah yang mendasarinya berkiblat pada nilai-nilai individualisme dan liberalisme yang sangat bertolak belakang dengan hukum konstitusi. Sehingga KUHP sekarang ini dapat dikatakan tidak relevan lagi dengan tuntutan perkembangan pemikiran hukum dan dinamika masyarakat Indonesia yang berlandaskan kepada Pancasila.

Yang menjadi sorotan sangat tajam dan yang paling dikritisi dalam upaya pembaruan KUHP ialah penyerapan hukum terhadap rumusan tindak pidana perzinaan. Khususnya sorotan kritis terhadap delik perzinaan yang telah mengalahkan pembahasan delik-delik lain yang digagas dalam Konsep RUU-KUHP. Rumusan tindak pidana perzinaan dalam Pasal 284 KUHP ialah perzinaan yang dilakukan oleh dua orang yang salah satu atau keduanya terikat hubungan perkawinan dan diadukan oleh isteri atau suami pelaku zina dan dilakukakan atas dasar suka sama suka, hukumannya maksimal sembilan bulan penjara. Untuk tindak pidana perzinaan ini KUHP menempatkannya sebagai tindak pidana aduan (delik aduan). Pengaturan ini membuka ruang dan kesempatan yang seluas-luasnya bagi merebaknya tindak pidana perzinaan dalam berbagai bentuk dan variasinya. Keberadaan Pasal 284 ini tentunya sudah sangat tidak relevan lagi dan tidak dapat dikatakan bahwa Pasal 284 tersebut ideal sebagai sebuah produk hukum yang menjamin tegaknya keamanan dan ketentraman dalam kehidupan masyarakat sebagaimana tujuan hukum yang di cita-citakan (ius constituendum). Pada kenyataannya substansi dari pasal 284 tersebut tidak mampu lagi mencerminkan dan mengakomodir nilai-nilai hukum yang hidup dalam masyarakat, baik hukum adat maupun hukum agama, yang mana disebut-sebut sebagai gagasan pembentuk hukum konstitusi. ${ }^{1}$

Seperti contoh kasus asusila (zina) anggota DPR Yahya Zaini-Maria Eva dan Ariel-Cut Tari. Kedua kasus tersebut jelas memenuhi unsur sebagai tindak pidana zina, bahkan pelaku mengakui perbuatan tersebut dan publik pun mengetahuinya. Tetapi perbuatan tersebut tidak dapat dilakukan penuntutan karena tidak adanya aduan dari pihak-pihak yang dirugikan (keluarganya). Adapun ariel dipidana penjara karena melanggar ketentuan Undang-Undang ITE dengan menyebar luaskan film porno nya ke dunia maya, bukan karena perzinaannya.

Mengenai Pasal 284 KUHP ini, R. Soesilo menjelaskan bahwa yang dimaksud dengan zina adalah persetubuhan yang dilakukan oleh lakilaki atau perempuan yang telah terikat perkawinan dengan perempuan atau laki-laki yang bukan isteri atau suaminya. Supaya masuk dalam Pasal 284 ini, maka persetubuhan tersebut harus dilakukan dengan dasar suka sama suka, tidak boleh ada paksaan dari salah satu pihak. ${ }^{2}$

Apabila kita cermati lagi, ketentuan tindak pidana perzinaan dalam KUHP yang sedang berlaku saat ini bertujuan untuk mengkriminalisasi pelaku perselingkuhan dimana salah seorang atau keduanya terikat dengan ikatan perkawinan. Selain itu Pasal 284 KUHP ini merupakan delik aduan absolut yang tidak memungkinkan perbuatan itu dipidana jika tidak ada yang mengadukan dari pihak yang dirugikan, dan selama perkara itu belum

\footnotetext{
1 Arifin Ma'ruf, Delik Zina dalam RUU KUHP, Komunitas Pemerhati Konstitusi, dalam (https://kpkuinsuka.blogspot.com/2014/03/delikzina-

dalam-ruu-kuhp-arifin-maruf.html), diunggah bulan Maret 2014, diunduh tanggal 03 April 2017

${ }^{2}$ R. Soesilo, Kitab Undang-Undang Hukum Pidana (KUHP) Serta Komentar-Komentarnya Lengkap Pasal Demi Pasal (Bogor, 1976), hlm. 209
} 
diperiksa dimuka pengadilan, maka pengaduan tersebut dapat ditarik kembali. ${ }^{3}$

Dari hal tersebut, dapat disimpulkan bahwa perancang Pasal 284 tersebut yang ada saat itu merupakan Pemerintah Kolonial Belanda yang mengkriminalisasikan tindak pidana perzinaan dengan alasan untuk menjaga kesucian ikatan perkawinan bagi orang yang telah kawin. Selama kedua belah pihak yang melakukan persetubuhan ini belum terikat dengan ikatan perkawinan, maka delik perzinaan tersebut tidak dapat dikenakan.

Apabila merujuk pada ketentuan zina dalam rancangan Pasal 484 angka (1) sampai (4) RUU KUHP 2018 tersebut diketahui bahwa perbuatan zina merupakan tindakan persetubuhan yang dilakukan oleh kedua orang yang tidak terikat perkawinan yang sah, baik satu atau keduanya terikat dengan ikatan perkawinan maupun kedua-duanya belum terikat perkawinan. Tampak ada perluasan makna dalam delik baru ini dibandingkan dengan delik zina yang sedang berlaku sekarang. Akan tetapi delik dalam rumusan Pasal 484 ini masih menggunakan delik aduan. Inilah yang menjadi celah bagi masyarakat untuk melakukan perbuatan zina. Sehingga berdasarkan hal tersebut menarik untuk dikaji terkait perubahan sifat tindak pidana perzinaan di Indonesia dari tindak pidana aduan menjadi tindak pidana biasa.

\section{METODE PENELITIAN}

Jenis penelitian yang digunakan dalam penelitian ini adalah yuridis normatif. Dengan mengkaji persoalan hukum dari sudut pandang ilmu hukum secara mendalam terhadap norma hukum yang dibentuk. Adapun metode pendekatan yang digunakan dalam penelitian hukum ini ialah pendekatan undang-undang (statute approach), pendekatan kasus (case approach), pendekatan komparatif (comparative approach), dan pendekatan konseptual (conceptual approach). ${ }^{4}$

\footnotetext{
${ }^{3}$ Ibid

${ }^{4}$ Peter Mahmud Marzuki, Op.Cit. hlm. 133
}

Sedangkan metode analisis yang digunakan dalam penilitian ini adalah deskriptif kualitatif. Deskriptif adalah bahan hukum yang terkumpul disusun untuk kemudian dianalisis dan hasilnya dideskripsikan atau dipaparkan secara sistematis. Sedangkan bahan hukum kualitatif adalah dengan menganalisis bahan hukum yang bertitik tolak pada usaha-usaha penemuan asas-asas dan informasi-informasi yang bersifat ungkapan monografis dari responden atau dengan kata lain lebih menitikberatkan pada mutu (kualitas) bahan hukum yang pada akhirnya akan diperoleh pemahaman yang lebih mendalam. ${ }^{5}$

\section{HASIL DAN PEMBAHASAN}

\section{Pertimbangan Perlunya Perubahan Sifat}

Tindak Pidana Perzinaan dari Tindak

Pidana Aduan (Delik Aduan) menjadi

Tindak Pidana Biasa (delik Biasa)

Perlu untuk mencermati putusan-putusan pengadilan terkait dengan tindak pidana zina sebagai bahan pertimbangan untuk menganalisis perlunya perubahan sifat tindak pidana perzinaan menjadi tindak pidana biasa (delik biasa).

\section{a) Putusan-Putusan Pengadilan di Indonesia terhadap Kasus Tindak Pidana Perzinaan}

1) Putusan Pengadilan Negeri Serang (Nomor : 559/Pid. B/2011/PN.Srg) terhadap Tindak Pidana Perzinaan atas nama terdakwa Toha bin Samsuri;

2) Putusan Pengadilan Negeri Mamuju (Nomor: $138 \quad$ /Pid.B/2010/PN.Mu.) terhadap Tindak Pidana Perzinaan atas nama terdakwa Ita Sari Darmawati;

3) Putusan Mahkamah Agung (Nomor. 1558 K/Pid/2012) terhadap Tindak Pidana Perzinaan atas nama terdakwa Sri Wahyuni.

Dimana ketiga Terdakwa pada kasus diatas diputus bersalah oleh Hakim karena telah memenuhi unsur Pasal 284 KUHP tentang

5 Rony Hanitijo Soemitro, Metodologi Penelitian Hukum dan Jurimetri (Jakarta, 1990), hlm. 97 
Tindak Pidana Perzinaan. Ketiga kasus yang telah diputus diatas merupakan kasus tindak pidana perzinaan yang diadukan oleh suami/istri nya masing-masing, apabila perbuatan tersebut tidak diadukan meskipun secara jelas perbuatan tersebut memenuhi unsur tindak pidana perzinaan maka pelaku zina tersebut tidak dapat diproses secara hukum. Artinya apabila tindak pidana perzinaan yang berlaku sekarang ataupun yang sedang dalam rancangan masih menggunakan delik aduan, maka perbuatan zina masih akan terus terjadi. Oleh karena itu perlu adanya perubahan sifat tindak pidana perzinaan zina yang semula tindak pidana aduan (delik aduan) menjadi tindak pidana biasa (delik biasa).

\section{b) Gambaran Kondisi dan Reaksi Masyarakat terhadap Perzinaan}

Pada hakikatnya kalau dicermati dalam kondisi kebangsaan kita, sifat keberlakuan delik perzinaan berlaku terbatas. Sebab masih terdapat model perzinaan yang oleh masyarakat kita menganggapnya perbuatan tercela tetapi KUHP tidak menggolongkannya sebagai tindak pidana. Diantaranya ialah:

1) Laki-laki dan perempuan yang melakukan hubungan "setubuh" suka sama suka namun kedua-duanya tidak terikat dengan perkawinan (fornication), tetapi pada dasarnya masih bisa melangsungkan perkawinan karena tidak ada pertalian darah yang menghalanginya;

2) Laki-laki dan perempuan yang mengadakan hubungan setubuh sama-sama belum menikah, suka sama suka, tetapi pada dasarnya hubungan setubuh itu sangat terlarang oleh karena terdapat ketentuan pelarangan perkawinan sedarah (incest), misalnya hubungan setubuh antara saudara sekandung, antara ibu dan anak, antara anak dan bapak;

3) Hubungan setubuh antara laki-laki dan perempuan yang mana salah satunya sudah terikat dengan perkawinan (misalnya lakilaki sudah menikah) lalu melakukan hubungan setubuh dengan keluarganya yang dilarang untuk dinikahi karena larangan perkawinan sedarah. Contoh konkretnya, bapak/ayah yang melakukan hubungan setubuh atas dasar suka sama suka dengan anaknya yang sudah dewasa.

Pada bagian ketiga pembagian perzinaan di atas, berdasarkan KUHP masih tergolong sebagai tindak pidana. Hanya saja delik tersebut masih berlaku sebagai delik aduan absolut. Sehingga kasus demikian pun bisa diproses secara hukum kalau si suami/istri mengajukan aduan terhadap perbuatan tersebut.

Sedangkan untuk angka 1 maupun angka 2, satupun tidak ada pengaturannya dalam KUHP. Maka di sinilah letak kejanggalan hukumnya. Bahwa problematika hukum pidana terhadap perbuatan perzinaan yang dibatasi hanya pada persetubuhan ketika pelakunya, laki-laki atau perempuan terikat dengan perkawinan tetapi mengadakan hubungan setubuh dengan yang bukan pasangan nikahnya, berdasarkan pandangan hukum masyarakat Indonesia penggolongan perzinaan tersebut kurang lengkap karena:

1) Masyarakat memandang semua jenis perbuatan zina, baik yang terikat ataupun yang tidak terikat dengan perkawinan, apalagi perzinaan yang terjadi karena adanya larangan perkawinan sedarah semuanya adalah kejahatan (rech delicten);

2) Kehendak masyarakat kita memandang kalau perzinaan merupakan perbuatan yang amat tercela sehingga seharusnya semua jenis atau bentuk perzinaan harus menjadi delik biasa. Yakni kalau sudah terjadi perzinaan lengkap dengan buktibuktinya, tak perlu ada pihak pengadu yang ditunggu agar kasus tersebut dapat diproses secara hukum. ${ }^{6}$

Sedangkan dalam kenyataan sosial masyarakat, aturan pidana yang kurang layak sering menjadi objek ketidakpuasan yang akhirnya menumbuhkan reaksi sosial. KUHP yang berlaku sekarang belum memberikan rasa

6 Damang Averroes Al-Khawarizmi, Formulasi Delik Perzinaan, dalam (http://www.negarahukum.com/hukum/formulasi-delikperzinahan.html), diunggah tanggal 25 April 2015, diunduh tanggal 17 Februari 2018 
keadilan kepada masyarakat. Kondisi tersebut dimungkinkan terjadi karena pengertian kejahatan menurut hukum pidana berbeda dengan pengertian kejahatan menurut masyarakat. Berkaitan dengan hal tersebut terjadi ketidakpuasan dari sebagian masyarakat mengenai perilaku-perilaku penyimpangan terutama dalam lingkup kesusilaan. Hal ini disebabkan karena perilaku-perilaku yang menyimpang dari norma-norma masyarakat belum mendapat tempat semestinya dalam hukum pidana. Misalnya perbuatan zina yang menurut pengertian masyarakat berbeda dengan pengertian dalam Hukum Pidana Indonesia (KUHP). Masyarakat menganggap bahwa zina adalah perbuatan yang patut mendapatkan sanksi pidana, adat dan sosial serta siapa saja boleh melaporkannya, sementara KUHP yang berlaku cenderung sanksi yang diberikan masih ringan dan yang melapor terbatas hanya suami/istri pelaku zina.

Berdasarkan kondisi hukum yang berkembang di masyarakat kita. Maka dalam konteks sekarang memang sudah saatnya merumuskan kembali tindak pidana perzinaan yang semula merupakan tindak pidana aduan (delik aduan) menjadi tindak pidana biasa (delik biasa).

\section{c) Kasus Perzinaan yang Tidak Diadukan}

Kasus tindak pidana perzinaan yang tidak diadukan seperti kasus video porno anggota dewan Yahya Zaini dengan seorang artis Maria $\mathrm{Eva}^{7}$ dan kasus beredarnya video porno yang melibatkan Ariel dan Cut Tari yang keduanya sama-sama sudah diketahui oleh publik namun tidak proses secara pidana dalam konteks perzinaannya. Yahya Zaini dan Maria Eva tidak di proses secara pidana karena pihak ketiga dalam hal ini ialah isteri dari Yahya Zaini maupun suami dari Maria Eva tidak mengadukannya. Begitupun dengan kasus video porno Ariel-Cut Tari yang tidak diproses

7 No Name, Skandal Seks Anggota Dewan yang Terendus Publik, diupload pada hari selasa tanggal 24 April 2012, 09:45 WIB dalam detik news diakses melalui Google tanggal 12 Juli 2018 karena perzinaannya, tetapi Ariel diputus dengan Pasal Pornografi dan UU ITE.

Jika dilihat dari kasusnya, sebetulnya kedua kasus tersebut dapat dikenakan delik perzinaan, namun sayang dalam Pasal 284 KUHP disyaratkan adanya pengaduan. Sehingga kasus tersebut tidak dapat diajukan lebih lanjut kedalam masalah perzinaannya karena tidak ada pihak ketiga (suami/isteri) yang mengadukan.

Meskipun Ariel tidak didakwa dengan pasal perzinaan, bukan berarti perbuatan zina yang telah dilakukan Ariel dengan Cut Tari bukan merupakan suatu kejahatan. Status Hukum delik perzinaan yang telah dilakukan oleh Ariel-Cut Tari dan sudah diketahui publik menurut hukum positif di Indonesia (KUHP) tetap disebut sebagai kejahatan (delik), akan tetapi dalam pertanggungjawabannya terhadap Ariel dan Cut Tari, penegak hukum dalam hal ini penyidik, tidak melakukan tindakan hukum dikarenakan tidak dipenuhinya unsur aduan dari suami Cut Tari yang menjadi syarat mutlak dari dapat dikatakan adanya delik perzinaan menurut KUHP Indonesia. Hal itu disebabkan karena perzinaan termasuk dalam delik aduan yang mutlak diperlukan adanya aduan dari pihak yang merasa dirugikan dalam hal ini suami Cut Tari yakni Yusuf Subrata atau dari isteri Ariel.

Adanya delik perzinaan yang secara nyata sudah diketahui oleh publik, akan tetapi tidak diproses oleh penegak hukum dikarenakan tidak terpenuhinya unsur adanya aduan dari pihak yang merasa dirugikan yakni suami/istri dari pelaku zina, dapat menimbulkan berbagai macam persoalan. Kasus video porno Yahya Zaini-Maria Eva dan Ariel-Cut Tari yang tersebar di media massa pada awal bulan Juni 2010 lalu menjadi cikal-bakal pengetahuan publik tentang telah terjadinya perzinaan antara Ariel dengan Cut Tari. Pada kondisi riil di masyarakat, video porno tersebut menimbulkan gejolak yang dahsyat, karena sesuai dengan budaya dan struktur masyarakat Indonesia yang mayoritas muslim, menganggap bahwa zina adalah perbuatan yang sangat keji dan termasuk dosa besar. 
d) Alasan Pembenar Perlunya Perubahan Sifat Tindak Pidana Perzinaan dalam KUHP Indonesia yang Akan Datang dari Tindak Pidana Aduan (Delik Aduan) Menjadi Tindak Pidana Biasa (Delik Biasa)

Alasan-alasan pembenar kenapa tindak pidana perzinaan harus dijadikan sebagai tindak pidana biasa (delik biasa).

1) Berdasarkan Teori Kriminalisasi

Kriminalisasi dapat diartikan juga sebagai proses penetapan suatu perbuatan seseorang sebagai perbuatan yang dapat di pidana. Proses kriminalisasi ini biasanya diakhiri dengan terbentuknya undang-undang dimana perbuatan itu diancam dengan sanksi yang berupa pidana. ${ }^{8}$ Perbuatan-perbuatan yang perlu di kriminalisasi ialah perbuatan-perbuatan yang secara langsung mengganggu ketertiban masyarakat. Dalam hal ini perbuatan zina adalah perbuatan yang dapat mengganggu ketertiban masyarakat, bahkan perbuatan zina tersebut dapat meresahkan masyarakat yang akan berdampak kepada kenyamanan dan ketertiban masyarakat.

Kebijakan kriminalisasi merupakan suatu kebijakan dalam menetapkan suatu perbuatan yang semula bukan tindak pidana menjadi suatu tindak pidana. Jadi pada hakikatnya kebijakan kriminalisasi merupakan bagian dari kebijakan kriminal (criminal policy) dengan menggunakan sarana hukum pidana sehingga termasuk bagian dari kebijakan hukum pidana (penal policy). ${ }^{9}$

Berkenaan dengan masalah kriminalisasi tersebut, menurut Sudarto dalam melakukan kebijakan kriminalisasi harus memperhatikan hal seperti penggunaan hukum pidana harus memperhatikan tujuan pembangunan nasional, yaitu mewujudkan masyarakat adil dan makmur yang merata material maupun spiritual berdasarkan Pancasila, dan perbuatan yang diusahakan untuk dicegah atau ditanggulangi dengan hukum pidana harus merupakan

${ }^{8}$ Sudarto, Kapita Selekta Hukum Pidana (Bandung, 1986), hlm. 31

${ }^{9}$ Barda Nawawi Arief, Tindak Pidana Mayantara : Perkembangan Kajian Cyber Crime di Indonesia (Jakarta, 2007), hlm. 20 perbuatan yang tidak dikehendaki, yaitu perbuatan yang mendatangkan kerugian baik secara material dan spiritual atas warga masyarakat.

Perbuatan zina merupakan perbuatan yang dapat menggagu kenyamanan masyarakat, meskipun perbuatan zina tersebut dikehendaki oleh pelaku. Perbuatan zina sudah membuat resah masyarakat yang akan berdampak terganggunya kenyamanan masyarakat sehingga mengakibatkan terjadinya kerugian material maupun spiritual terhadap masyarakat khsusunya masyarakat dilingkungan sekitar. Sehingga menurut pendapat Sudarto ini bisa ditarik kesimpulan bahwa pelaku zina sekalipun dilakukan atas dasar suka sama suka dan dikehendaki oleh si pelaku dapat dipidana (dapat dikriminalisasi).

2) Berdasarkan Kebutuhan Masyarakat

Masuknya budaya luar dan adanya celah hukum berdampak pula kepada masyarakat, dimana perbuatan hubungan badan diluar nikah (zina) sering terjadi, bahkan hal tersebut sudah dianggap biasa bagi kalangan masyarakat khususnya para pemuda kita. Perilaku tersebut tentunya akan menimbukan kerusakan moral kepada masyarakat kita.

Selain karena masuknya budaya luar, ada faktor lain yang membuat masyarakat banyak melakukan perbuatan terlarang seperti berhubungan badan yang bukan muhrimnya (zina). Faktor tersebut ialah tidak adanya aturan hukum yang pasti terhadap pelaku zina, hal tersebut tercermin dalam Pasal 284 KUHP tentang zina. Dimana pasal tersebut terdapat celah yang dapat dimanfaatkan oleh masyarakat untuk dapat menghindari sanksi atau hukuman pidana, seperti apabila yang melakukan samasama tidak terikat perkawinan maka hal tersebut bukanlah termasuk kedalam tindak pidana zina, dan celah lainnya ialah apabila tidak ada pihak ketiga yang di rugikan melapor maka perbuatan tersebut tidak dapat di proses secara hukum.

Kasus-kasus yang terjadi, seperti kasus sepasang kekasih di Tanggerang yang diarak dan telanjangi oleh warga karena dituduh berbuat mesum (zina) dilingkungannya, tidak 
hanya diarak dan ditelanjangi, pasangan tersebut juga di video dalam kondisi hampir telanjang bulat dan disebar luaskan di dunia maya. Ini dikarenakan belum adanya kepastian hukum bagi pelaku zina, sehingga masyarakat mengambil tindakan dengan main hakim sendiri untuk memberikan pelajaran dan membuat jera pelaku mesum tersebut, dengan harapan kejadian tersebut tidak terulang kembali.

Tentunya hal tersebut tidak dapat dibiarkan begitu saja, mengingat kebutuhan masyarakat akan hukum yang baik sangat diperlukan. Oleh karena itu, demi mewujudkan bangsa Indonesia sebagai bangsa yang bermoral maka perlu aturan hukum yang tegas yang sesuai dengan konstitusi bangsa Indonesia yakni Pancasila. Perlu adanya perubahan formulasi baru dalam Pasal 284 KUHP tentang zina ialah dengan menjadikan Pasal 284 KUHP sebagai tindak pidana biasa (delik biasa).

\section{3) Berdasarkan Agama}

Tidak ada satu agamapun (agama samawi) yang membolehkan perbuatan zina. Dalam islam zina merupakan perbuatan yang tercela yang dilarang oleh Allah. Sebagai negara yang mayoritas islam dan berdasarkan ketentuan konstitusi yakni Pancasila sila pertama berbunyi ketuhanan yang maha esa. Maka sejatinya hukum positif kita harus mempertimbangkan agama dan Pancasila sebagai dasar pembentukannya.

Allah berfirman yang artinya: "Dan janganlah kamu mendekati zina,; sesungguhnya zina itu adalah suatu perbuatan yang keji, dan suatu jalan yang buruk". (Q.S. 17 : 32)

Sayyid Qutub Menulis bahwa perzinaan terdapat pembunuhan dalam beberapa segi, Pertama pada penempatan seba kehidupan (sperma) bukan pada tempatnya yang sah. Ini biasanya disusul keinginan untuk menggugurkan, yakni membunuh janin yang dikandung. Kalau dilahirkan hidup, maka biasanya ia dibiarkan begitu saja tanpa ada yang memelihara dan mendidiknya, dan ini merupakan salah satu bentuk pembunuhan.

Disisi lain perzinaan juga membunuh masyarakat dari segi kemudahan atau melampiaskan nafsu, sehingga kehidupan rumah tangga menjadi sangat rapuh, padahal ia merupakan wadah yang terbaik untuk mendidik dan mempersiapkan generasi muda memikul tanggung jawabnya. Demikian lebih kurang yang ditulis oleh Sayyid Qutub, ketika menghubungkan ayat ini dengan ayat yang lalu dan mendatang. ${ }^{10}$

Berdasarkan ketentuan agama diatas (agama yang samawi), maka sudah saatnya delik zina dijadikan sebagai delik biasa dan dituangkan dalam KUHP Indonesia yang berlaku pada masa yang akan datang.

e) Landasan Filosofis, Sosiologis, dan Yuridis Perlunya Perubahan Sifat Tindak Pidana Perzinaan dari Tindak Pidana Aduan Menjadi Tindak Pidana Biasa

Landasan filosofis, sosiologis dan yuridis adalah pertimbangan atau alasan perlunya Kitab Undang-Undang Hukum Pidana Nasional yang baru dibentuk, khusunya pada bagian tindak pidana perzinaan dengan memperhatikan: (1) pandangan hidup dan kesadaran dan cita hukum yang bersumber pada Pancasila dan Pembukaan UUD NRI tahun 1945, (2) memperhatikan pemenuhan kebutuhan hukum masyarakat dan negara terkait dengan perkembangan fakta empiris mengenai hukum pidana nasional, serta (3) memperhatikan aturan-aturan yang telah ada sehingga akan berdampak pada substansi atau materi yang akan diatur.

1) Landasan Filosofis

Dalam konteks pembaruan hukum pidana di Indonesia dalam hal ini adalah tindak pidana zina harus dilandaskan pada tujuan nasional yang ingin dicapai oleh bangsa Indonesia sebagai sebuah negara yang merdeka dan berdaulat. KUHP yang saat ini masih berlaku merupakan produk hukum pemerintah Kolonial Hindia Belanda, yang perlu disesuaikan. Alinea keempat Pembukaan UUD NRI Tahun 1945 harus dijadikan tolak ukur untuk pelaksanaan pembaharuan tersebut. Dengan kata lain pembaharuan hukum pidana harus menjadi

10 M.Quraish Shihab, Tafsir Al- Misbah (Jakarta; Lentera Hati ,2002), hlm. 458. 
sarana untuk melindungi segenap bangsa Indonesia dan seluruh tumpah darah Indonesia, memajukan kesejahteraan umum, mencerdaskan kehidupan bangsa, dan ikut melaksanakan ketertiban dunia yang berdasarkan kemerdekaan, perdamaian abadi dan keadilan sosial. Materi hukum pidana nasional harus disesuaikan dengan politik hukum, keadaan, perkembangan kehidupan berbangsa dan bernegara yang bertujuan menghormati dan menjunjung tinggi hak asasi manusia, serta menciptakan keseimbangan berdasarkan nilai moral religius Ketuhanan Yang Maha Esa, kemanusiaan, kebangsaan, kerakyatan, dan keadilan sosial bagi seluruh rakyat Indonesia.

2) Landasan Sosiologis

Secara sosiologis, pembaharuan hukum dilakukan karena adanya kehendak untuk memenuhi kebutuhan hukum masyarakat yang sudah diupayakan sejak 46 tahun yang lalu. Kebutuhan ini didasarkan pada nilai-nilai kebudayaan dari suatu bangsa (latency) yang merdeka dan berdaulat.

Kondisi internal masyarakat Indonesia yang berkembang cepat seiring perkembangan yang terjadi di dunia internasional serta adanya tuntutan akan kepastian hukum dan keadilan yang begitu kuat, menyebabkan beberapa rumusan hukum pidana yang dimuat dalam KUHP tidak lagi dapat dijadikan dasar hukum untuk mengatasi problem kejahatan, seperti halnya yang terkandung dalam rumusan Pasal 284 KUHP tentang tindak pidana perzinaan.

Perlu untuk diketahui bahwa masyarakat Indonesia merupakan masyarakat yang beragama dan menganut sistem ketuhanan sebagaimana yang tertuang dalam Pancasila sila pertama yakni "Ketuhanan yang Maha Esa". Berdasarkan hal tersebut, seharusnya interpretasi dalam merumuskan suatu kebijakan atau peraturan perundang-undangan harus memasukkan unsur-unsur agama.

Sebagaimana dikemukakan oleh Oemar Senoadji ${ }^{11}$ kejahatan terhadap kesusilaan ini,

11 Naskah Akademik RUU-KUHP, Mengutip pernyataan Oemar Senoadji bahwa "sekitar kejahatan dalam mengisi dan mengarahkan delik-delik susila, seharusnya unsur-unsur agama memegang peranannya.

3) Landasan Yuridis

KUHP yang berlaku di Indonesia sekarang ini berasal dari Wetboek van Strafrecht voor Nederlandsch-Indie (Stb. 1915: 732). Setelah diundangkannya Undang-Undang Nomor 73 Tahun 1958 tentang "Menyatakan Berlakunya Undang-Undang No. 1 Tahun 1946 Republik Indonesia Tentang Peraturan Hukum Pidana Untuk Seluruh Wilayah Republik Indonesia dan Mengubah Kitab Undang-Undang Hukum Pidana”, terwujud kesatuan hukum pidana materiel yang seragam untuk seluruh Indonesia yang bersumber pada "Wetboek van Strafrecht voor Nederlandsch-Indie", yang untuk selanjutnya disebut Kitab Undang-Undang Hukum Pidana.

Pada era kemerdekaan telah dilakukan banyak usaha untuk menyesuaikan KUHP warisan kolonial dengan kedaulatan Indonesia dan dengan perkembangan kehidupan sosial lainnya, baik nasional maupun internasional. Apabila dicermati, pembaharuan dan/atau perubahan yang dilakukan masih bersifat sementara (ad hoc) dan bernuansa evolusioner.

Dalam hal ketentuan tindak pidana perzinaan (delik zina), sampai rancangan yang terbaru tahun 2018 delik zina masih merupakan delik biasa, yang terbaru hanya ada perluasan unsur dimana seorang laki-laki dengan perempuan yang sama-sama bujang melakukan persetubuhan (zina) merupakan perbuatan zina. Hal ini berbeda dengan unsur zina dalam KUHP yang berlaku sekarang, dimana jika seorang laki-laki dengan perempuan yang sama-sama bujang melakukan persetubuhan (zina) tidak dapat dipidana.

\section{Formulasi Tindak Pidana Perzinaan dalam KUHP Indonesia yang Akan Datang Agar Bersifat Tindak Pidana Biasa (Delik Biasa)}

terhadap kesusilaan ini bahwa dalam mengisi dan mengarahkan delik-delik susila itu, seharusnyalah unsurunsur agama memegang peranannya". 
Untuk menyusun formulasi tindak pidana perzinaan dalam KUHP Indonesia yang akan datang agar bersifat tindak pidana biasa (delik biasa) maka perlu untuk mengetahui kondisi dan perkembangan hukum pidana di Indonesia, dan juga perlu untuk mengkaji dari aspek teoritik pembentukan serta perubahan hukum dan perundang-undangan, mengetahui konsep zina diluar Indonesia dan konsep zina dalam Rancangan KUHP Indonesia.

\section{a) Kondisi dan Perkembangan Hukum Pidana Positif di Indonesia}

Hukum pidana positif di Indonesia saat ini terdiri dari KUHP dan berbagai UndangUndang khusus di luar KUHP. Kondisi dan perkembangan KUHP warisan pemerintah Hindia Belanda telah mengalami perubahan, baik aturan umumnya maupun aturan khususnya.

Perkembangan aturan umum Buku I KUHP sejak Undang- Undang Nomor 1 Tahun 1946 sampai saat ini, tidak mengalami perubahan yang mendasar. Dikatakan demikian, karena asas-asas atau prinsip-pinsip umum (general principle) hukum pidana dan pemidanaan yang ada dalam KUHP masih seperti $W v S$ Hindia Belanda. Memang di dalam perkembangannya ada perubahan, penambahan, dan pencabutan beberapa pasal di dalam aturan umum Buku I, namun hal itu hanya perubahan parsial yang tidak mengubah keselurahan sistem pemidanan.

Berdasarkan kondisi dan perkembangan hukum pidana positif di Indonesia, sampai saat ini belum ada perkembangan dari delik zina. Dimana, delik zina dalam KUHP maupun dalam RUU-KUHP masih sebagai tindak pidana aduan (delik aduan). Hal inilah yang menjadi celah dan tindak pidana zina terus terjadi di Indonesia. Oleh sebab itu, berdasarkan pada landasan filosofis, sosiologis, dan yuridis sebagaimana yang sudah dijelaskan diatas, maka perlu untuk melakukan perubahan sifat tindak pidana perzinaan menjadi tindak pidana biasa (delik biasa).

b) Aspek Teoritik Pembentukan dan Perubahan Hukum dan PerundangUndangan
Menurut pandangan penulis, perubahan terhadap undang-undang atau perubahan terhadap salah satu pasal dalam undang-undang dapat dilakukan jika hal tersebut dirasa tidak sesuai dengan budaya bangsa kita. Sebagaimana pendapat Von Savigny yang menganalogikan timbulnya hukum itu dengan timbulnya bahasa di suatu bangsa. Masingmasing bangsa memiliki ciri-ciri yang khusus dalam berbahasa. Hukumpun demikian, karena tidak ada bahasa yang universal, tiada pula hukum yang universal. ${ }^{12}$

Sehingga pada Pasal 284 KUHP tentang perzinaan dapat dilakukan perubahan atau reformulasi, dimana selama ini unsur-unsur dalam rumusan Pasal 284 KUHP tersebut bertentangan dengan budaya asli banga Indonesia. Oleh karena itu perlu adanya perubahan terhadap Pasal tersebut agar sesuai dengan budaya bangsa Indonesia. Perubahanperubahan tersebut salah satunya ialah dengan memasukkan rumusan baru yang sebelumnya belum ditur dalam Pasal 284 KUHP ini. Diantara ialah:

1) Memperluas unsur tindak pidana zina yang semula hanya salah satu atau keduanya terikat perkawinan menjadi kedua-duanya baik terikat maupun sama-sama tidak terikat perkawinan. Hal ini sudah diatur dalam RKUHP 2015.

2) Menjadikan tindak pidana zina yang semula merupakan tindak pidana aduan (delik aduan absolute) menjadi tindak pidana biasa (delik biasa).

Dengan demikian, kedepannya apabila reformulasi Pasal 284 KUHP ini diterapkan, diharapkan dapat mencegah perbuatan zina. Sebagaimana budaya bangsa Indonesia yang tidak melegalkan perbuatan zina, baik sebelum menikah ataupun sesudah menikah. Apabila perbuatan tersebut dilakukan, maka menurut masyarakat itu tetap sebagai perbuatan yang tercela dan bertentangan dengan nilai-nilai budaya bangsa Indonesia dan Agama.

12 Sukarno Aburera, et.al, Filsafat Hukum Teori dan Praktik (Jakarta, 2013), hlm. 119 
c) Perbandingan Hukum Tindak Pidana Zina di Luar Indonesia

Berdasarkan fakta-fakta tersebut, maka realitas perbedaan sistem hukum dibeberapa negara, menjadi faktor penyebab utama pentingnya melakukan perbandingan hukum, karena dengan mempelajari perbandingan hukum membawa faedah untuk bidang kultural tentang hukum diberbagai negara sehingga dapat lebih luas dan kritis dalam memahami hukum dinegaranya sendiri. ${ }^{13}$

Perbedaan persepsi dalam memandang zina dalam dua sistem hukum di dua negara yang memiliki ideologi yang berbeda merupakan hal yang menarik dan penting untuk dikaji, dalam hal ini yang akan dibuat perbandingan dengan konsep hukum tindak pidana perzinaan Indonesia dengan konsep hukum tindak pidana perzinaan dari beberapa Negara lain. Diantara adalah sebagai berikut:

1) Delik Zina dalam KUHP Republik Korea

Ada beberapa perbedaan antara delik mukah (overspel/zina) korea dengan KUHP Indonesia yang lama. Perbedaan pertama ialah ancaman pidana dalam KUHP Korea lebih berat, yaitu maksimum 2 (dua) tahun, sedangkan dalam Pasal 284 KUHP lama Indonesia maksimum 9 (sembilan) bulan. Perbedaan selanjutnya dalam KUHP korea dicantumkan secara tegas, bahwa suami/isteri memanfaatkan mukah (overspel/zina) itu, maka pengaduan tidak dapat ditarik. Ini berbeda dengan KUHP Indonesia, dimana dalam KUHP Indonesia pengaduan dapat ditarik kembali selama belum masuk dalam proses persidangan. ${ }^{14}$

2) Delik Zina dalam KUHP Argentina

Delik zina dalam KUHP Argentina diatur dalam Pasal 118 tentang mukah (overspel/zina). Perbedaan delik antara KUHP Argentina dengan KUHP Indonesia terletak pada bagian pengaduan, dalam KUHP Argentina jika yang mengadukan telah meninggal dunia, maka hak

13 Munir Fuady, Perbandingan Ilmu Hukum (Bandung: Refika Aditama, 2007), hlm. 19

14 Andi Hamzah, Perbandingan Hukum Pidana Beberapa Negara, Edisi I Cetakan ke-II (Jakarta, 1995), hlm. 55 menuntut hilang, dan jika telah diputus pidana tidak dapat dijalankan (pasal 74) KUHP Argentina. ${ }^{15}$

\section{3) Delik Zina dalam KUHP Malaysia}

Dalam KUHP Malaysia tidak mengatur secara rinci terkait delik zina. Hal ini tercermin dalam BAB IV yang hanya membahas tentang delik-delik terhadap kesehatan umum, keselamatan, kesenangan, kesopanan dan kesusilaan. Kalau kita telaah lebih lanjut terkait bab ini, tidak ada yang mengatur secara rinci terkat delik zina, yang ada hanya mengatur secara berurut dan terperinci dari delik kebisingan, kesehatan lingkungan, termasuk penjualan makanan, minuman dan obat yang merusak kesehatan, pencemaran air dan udara, sampai pada keselamatan lalu lintas dijalanan dan navigasi kapal.

Oleh sebab itu dapat ditarik kesimpulan bahwa KUHP Malaysia ini termasuk KUHP yang kuno (ketinggalan jaman) jika dibandingkan dengan Indonesia. Bagaimana mungkin negara Malaysia yang merupakan negara serumpun dengan Indonesia bahkan budaya nya hampir sama dengan Indonesia dan warganya mayoritas beragama islam tidak mengatur secara terperinci terkait dengan delik zina. ${ }^{16}$

\section{d) RUU-KUHP (Rancangan Undang- Undang Kitab Undang-Undang Hukum Pidana) 2018}

Dalam RUU-KUHP 2018 per tanggal 5 Februari, Tindak Pidana Zina diatur dalam Pasal 484 angka (1) sampai (4). Adapun bunyi Pasal itu sendiri yaitu:

\section{Pasal 484}

(1)Dipidana karena zina, dengan pidana penjara paling lama 5 (lima) tahun:

a. Laki-laki yang berada dalam ikatan perkawinan melakukan persetubuhan dengan perempuan yang bukan istrinya;

b. Perempuan yang berada dalam ikatan perkawinan melakukan persetubuhan dengan laki-laki yang bukan suaminya;

\footnotetext{
${ }^{15}$ Andi Hamzah, Ibid, hlm. 81

${ }^{16} \mathrm{Ibid}, \mathrm{hlm} .76$
} 
c. Laki-laki yang tidak dalam ikatan perkawinan melakukan persetubuhan dengan perempuan, padahal diketahui bahwa perempuan tersebut berada dalam ikatan perkawinan;

d. Perempuan yang tidak dalam ikatan perkawinan melakukan persetubuhan dengan laki-laki, padahal diketahui bahwa laki-laki tersebut berada dalam ikatan perkawinan; atau

e. Laki-laki dan perempuan yang masingmasing tidak terikat dalam perkawinan yang sah melakukan persetubuhan. (cetak miring, penulis)

(2) Tindak pidana sebagaimana dimaksud pada ayat (1) tidak dilakukan penuntutan kecuali atas pengaduan suami, isteri, orang tua atau anaknya.

(3) Terhadap pengaduan sebagaimana dimaksud pada ayat (2) tidak berlaku ketentuan Pasal 26, Pasal 27, dan Pasal 31.

(4) Pengaduan dapat ditarik kembali selama pemeriksaan di sidang Pengadilan belum dimulai.

Setelah melihat rumusan yang terkandung dalam RUU KUHP 2018 Pasal 484 angka (1-4) tentang Tindak Pidana Perzinaan dapat disimpulkan bahwa rumusan yang terkandung dalam RUU KUHP 2018 Pasal 484 ini belum bisa memberikan sebuah perlindungan hukum bagi masyarakat, karena masih ada celah bagi masyarakat untuk melakukan tindak pidana perzinaan, sekalipun unsur nya telah diperluas sebagaimana diatur dalam Pasal 484 tersebut.

\section{e) Rumusan Konsep Reformulasi Tindak Pidana Perzinaan}

Penulis menawarkan sebuah konsep atau formulasi baru terkait dengan tindak pidana perzinaan, dimana konsep atau formulasi yang ditawarkan ialah dengan cara mengganti delik nya, yang semula merupakan tindak pidana aduan (delik aduan absolute) menjadi tindak pidana biasa (delik biasa).

Dalam merumuskan konsep kebijakan reformulasi tindak pidana zina harus mempertimbangkan asas-asas pembentukan hukum. Dalam Pasal 6 Undang-undang Nomor 12 Tahun 2011 Tentang Pembentukan Peraturan Perundang-Undangan mengandung asas-asas, yaitu asas pengayoman, asas kemanusiaan, asas kebangsaan, asas kekeluargaan, asas kenusantaraan, asas bhinneka tunggal ika, asas keadilan, asas kesamaan kedudukan dan pemerintahan, asas ketertiban dan kepastian hukum, asas keseimbangan, keserasian dan keselarasan.

Adapun konsep atau kebijakan formulasi tindak pidana perzinaan yang baru ialah sebagai berikut:

1) Memperluas unsur tindak pidana zina yang semula hanya salah satu atau keduanya terikat perkawinan menjadi kedua-duanya baik terikat maupun sama-sama tidak terikat perkawinan. (sudah ada dalam rumusan RUU-KUHP)

2) Menjadikan tindak pidana zina sebagai tindak pidana biasa (delik biasa).

Konsep rumusan kebijakan reformulasi tindak pidana perzinaan yang ditawarkan berdasarkan asas-asas pembentukan hukum dan perubahan hukum adalah sebagai berikut:

\section{Pasal X}

(1) Dipidana karena perzinaan paling lama 5 (lima) tahun dan atau denda kategori II: ${ }^{17}$

a. Seorang laki-laki beristri yang melakukan persetubuhan dengan seorang atau lebih perempuan bujang atas dasar suka sama suka.

b. Seorang perempuan bersuami melakukan persetubuhan dengan seorang atau lebih laki-laki bujang atas dasar suka sama suka.

(2) Dipidana karena perzinaan dengan pidana penjara paling lama 7 (tujuh) tahun dan atau denda kategori III, ${ }^{18}$ laki-laki beristri melakukan persetubuhan dengan perempuan bersuami atas dasar suka sama suka.

17 Denda Kategori II ialah Rp. 30.000.000., sebagaimana dalam RUU-KUHP

18 Denda Ketgori III ialah Rp. 120.000.000., sebagaimana dalam RUU-KUHP 
(3) Laki-laki bujang dan perempuan bujang melakukan persetubuhan atas dasar suka sama suka di pidana dengan pidana penjara 3 (tiga) tahun dan atau denda kategori I. ${ }^{19}$

\section{Pasal XX}

Perzinaan sebagaimana dimaksud pada Pasal X yang dilakukan secara bersama-sama atau secara masal di pidana dengan pidana penjara 7 (tujuh) tahun atau denda kategiori III.

\section{Pasal XXX}

Pidana penjara ditambah sepertiga terhadap perzinaan yang dilakukan ditempat-tempat ibadah, tempat pendidikan, lingkungan kerja, kendaraan umum, atau tempat umum lainnya.

Rumusan formulasi tersebut merupakan hasil dari pertimbangan-pertimbangan berdasarkan asas-asas dan teori-teori pembentukan hukum dan perubahan hukum. Sehingga menghasilkan rumusan kebijakan formulasi tindak pidana perzinaan agar menjadi tindak pidana biasa (delik biasa).

\section{KESIMPULAN}

Berdasarkan hasil penelitian dan analisis terhadap hasil penelitian diatas, maka dapat disimpulkan bahwa:

1. Berdasarkan analisis terhadap putusanputusan pengadilan terkait kasus perzinaan, Gambaran kondisi dan reaksi masyarakat terhadap perilaku zina, kasuskasus zina yang tidak diadukan dan alasan pembenar perlunya perubahan sifat tindak pidana perzinaan, tindak pidana perzinaan merupakan perbuatan yang menyimpang dan tercela baik itu berdasarkan kondisi masyarakat maupun berdasarkan agama. Oleh sebab itu perlu untuk dilakukan perubahan sifat tindak pidana perzinaan yang semula merupakan tindak pidana aduan (delik aduan) menjadi tindak pidana biasa (delik biasa).

2. Agar bersifat tindak pidana biasa perlu dilakukan perubahan dengan mereformulasi Pasal 284 KUHP,

19 Denda Ketgori III ialah Rp. 6.000.000., sebagaimana dalam RUU-KUHP berdasarkan teori perubahan Perundangundangan itu dapat dilakukan selama pasal tersebut bertentangan dengan Pancasila. Dalam RUU-KUHP sekalipun ada perluasan unsur belum dapat memberikan rasa aman kepada masyarakat, karena delik yang digunakan dalam RUU-KUHP tersebut masih delik aduan.

\section{DAFTAR PUSTAKA \\ Buku-Buku:}

Aburera, Sukarno, et.al, 2013. Filsafat Hukum

(Teori dan Praktik), Jakarta:

Kencana.

Arief, Barda Nawawi, 2006. Tindak Pidana Mayantara : Perkembangan Kajian Cyber Crime di Indonesia, Jakarta: PT Raja Grafindo Persada.

Fuady, Munir, 2007. Perbandingan Ilmu Hukum, Bandung: Refika Aditama.

Hamzah, Andi, 1995. Perbandingan Hukum Pidana Beberapa Negara, Edisi I Cetakan ke-II, Jakarta: Sinar Grafika.

Shihab, M.Quraish. 2002. Tafsir Al- Misbah, Jakarta: Lentera Hati.

Soemitro, Rony Hanitijo, 1990. Metodologi Penelitian Hukum dan Jurimetri, Jakarta: Ghalia Indonesia.

Soesilo R., 1976. Kitab Undang-Undang Hukum Pidana (KUHP) Serta Komentar-Komentarnya Lengkap Pasal Demi Pasal, Bogor: Politeia.

Sudarto, 1986. Kapita Selekta Hukum Pidana, Bandung: Alumni.

\section{Website:}

Ma'ruf, Arifin, 2014. Delik Zina dalam RUU KUHP, Komunitas Pemerhati Konstitusi, dalam (https://kpkuinsuka.blogspot.com/20 14/03/delikzina-dalam-ruu-kuhparifin-maruf.html), diunggah bulan 
Maret 2014, diunduh tanggal 03 April 2017.

Damang, Formulasi Delik Perzinaan, diakses melalui

(http://www.negarahukum.com/huk um/formulasi-delik-

perzinahan.html), diunggah tanggal

25 April 2015, diunduh tanggal 17 Februari 2018.

No Name, Skandal Seks Anggota Dewan yang Terendus Publik, dalam Berita Detik News, diupload pada hari selasa 24 April 2012 jam 09:45 WIB.

\section{Peraturan Perundang-Undangan:}

Undang-Undang Dasar Negara Republik Indonesia Tahun 1945

Undang-Undang Nomor 1 Tahun 1946 tentang Pembentukan Hukum Pidana

\section{Rancangan Undang-Undang:}

Rancangan Kitab Undang-Undang Hukum Pidana (RUU-KUHP) 2015

Rancangan Kitab Undang-Undang Hukum Pidana (RUU-KUHP) 2018

\section{Putusan Pengadilan:}

Putusan Mahkamah Agung (Nomor. 1558 $\mathrm{K} / \mathrm{Pid} / 2012$ ) terhadap Tindak Pidana Perzinaan atas nama terdakwa Sri Wahyuni

Putusan Pengadilan Negeri Mamuju (Nomor : 138 /Pid.B/2010/PN.Mu.) terhadap Tindak Pidana Perzinaan atas nama terdakwa Ita Sari Darmawati

Putusan Pengadilan Negeri Serang (Nomor : 559/Pid. B/2011/PN.Srg) terhadap Tindak Pidana Perzinaan atas nama terdakwa Toha bin Samsuri 
